\title{
International Geological Congresses and Plate Tectonics
}

\section{by Charles L. Drake}

Some of the most important advances in our understanding of global processes in geology were first presented at an International Geological Congress. In this brief article, the President of the next IGC, to be held in Washington in 1989 , reviews some of these major steps in the progress of ideas that led to the modern concept of plate tectonics.

\section{Early Ideas}

In the cool days of early autumn in New Hampsinire, morning mists fill the valleys. As the sun ascends, it burns away these mists unveiling the local countryside and renewing confidence that the remembered features are still there. Several hundred years ago, when geology was beginning as a science and was practiced by natural philosophers from varied locations and with diverse backgrounds, the disappearance of the morning mists revealed markedly different worlds to each.

The principal tools of geology at that time were eyes, the data available to a given investigator tended to be geographically restricted; the body of experience was frequently self generated; the concepts that resulted were often restricted by social forces and unfettered by very much quantitative data. Given these circumstances, it is not surprising that widely varying ideas about the development of the Earth and its surface features were advanced, each defensible to some degree in terms of local geological features and local culture, but each globally limited by the body of experience and knowledge available to the advancing philosopher. This did not preclude constructive speculation about the development of the Earth's surface features, and concepts ranged from a youthful planet almost unchanged since an initial act of creation to an ancient Earth that reflected the current manilestations of continuous internal thernal activity throughout its history.

\section{The Search for an Acceptable Earth Model}

As geology matured as a science, its practitioners started to sort out the history recorded in the sediments and to speculate about the mysteries of the visible geological structures. With improved transportation and easier access to other parts of the world, geologists began to examine rocks far from their native haunts, to import new data, and to export their ideas. When Appalachian, Alpine, Andean, Atlas, or Altai geologists went afield to new regions, the interpretations they placed on these areas were understandably encumbered by the visions revealed when the mists lifted in their home area; they were not generated in innocence.

With growth of the body of geological knowledge, formerly isolated areas of investigation began to encroach upon each other, and cherished ideas about their history and development sometimes had to be sacrificed in order to produce a coherent, comprehensive picture of the geology of whole regions. Such sacrifices did not come easily, as we have seen a number of times in the past and will undoubtedly witness again in the future. We do not readily accept ideas that run counter to the common wisdom that we have accumulated over the years. This conservatism on our part is healthy in the sense that it demands that the proposer of a new concept demonstrate through observation or experiment the worth of the idea, but it may be less healthy if the concept is rejected solely because it is at odds with those currently accepted.

We now have a widely accepted nodel for the development of the surface features of the Earth in plate tectonics. The roots of this model date to the last century, with enigmatic distributions of fossil biota, geological features that were out of position in terms of their present latitudes, or geological similarities on different continents now separated by wide ocean basins. A number of theories, often unabashedly ad hoc, were advanced to account for these phenomena.

Elements of the plate tectonies model were used early in this century by Alfred Wegener (1912) to construct his continental drift theory. However, most of the geological community was not prepared to aceept his model at that time because it seemed mechanically unsound, because it moved too far from accepted common wisdom, and possibly because Wegener's background was in meteorology rather than geology. The strongest proponents were to be found in the Southern Hemisphere, where the geological and paleontological evidence was the most straightforward. Among the inost vigorous opponents were iNorth American geologists who had been raised in a tradition that favored fixed continents.

\section{The Rise of Mobilism}

At International Geological Congresses through the years, a broad-based international audience heard papers that had a bearing on the eventual plate tectonics model. At the 13 th IGC in Belgium (1922), for example, Emile Argand from Switzerland suggested that Africa over-rode Europe to produce the Alpine chains and that continued momentum carried them away from Africa producing the Mediterranean as a rift valley. IIe viewed Asia as overwhelming, on collision, the prow of India, which then underrode Asia, uplifting the Himalayas and the Tibetan Plateau (Fig. 1).

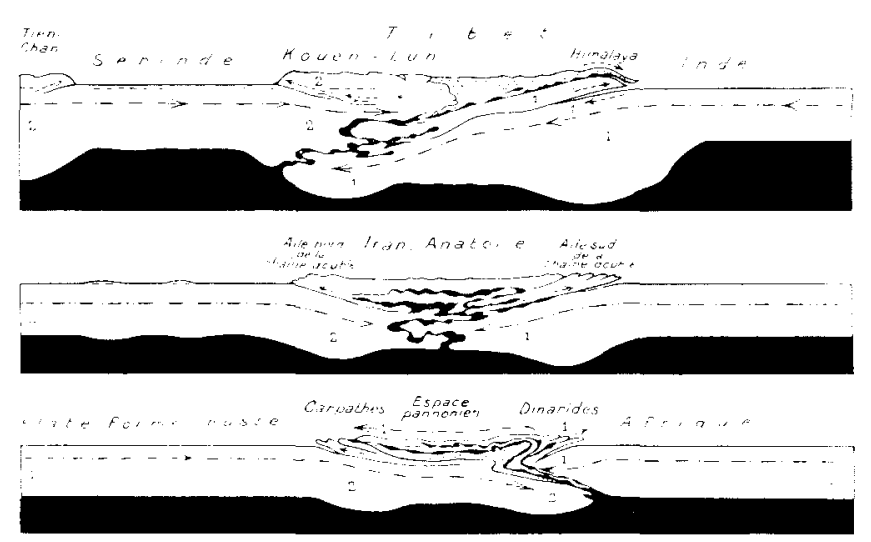

Figure 1: Argand's cross-sections of Tethys Eron Eurasia (2) to Gondwana (1). Continental blocks (white) floating over sima (black). Stipples indicate the "tectonic products" formed in the axial Tethyan zone. From Argand, 1922, Fig. 13-15. 
Argand recognized the battle between those who believed in the permanence in position of the continents ("fixists") and those who demanded large-scale horizontal movements ("mobilists"). He viewed the fixists as supporting an inertia of thought and viewed their principal mechanism, contraction, as totally at odds with isostasy in its demand for interchange of continental land bridges with abyssal ocean floor. He supported Wegener's theory, "Elle n'a pas refutée... On pense tenir une objection décisive, encore un coup et tout va craquer; mais rien ne craque; on n'a oublié qu'un ou plusieurs tours. C'est la résistance protéene d'un univers plastique."

Steinmann, from Germany, commented at the 14 th IGC in Madrid (1926) on the occurrence of serpentinized peridotites in association with spilitic pillow lavas and radiolarian chert, supposedly of deep water origin. He called the associations ophiolites, and these came to play a significant role in the plate tectonics model. Presumably the cherts and the pillow lavas were laid down during early formation of a geosyncline and the ultrabasic rocks came up later.

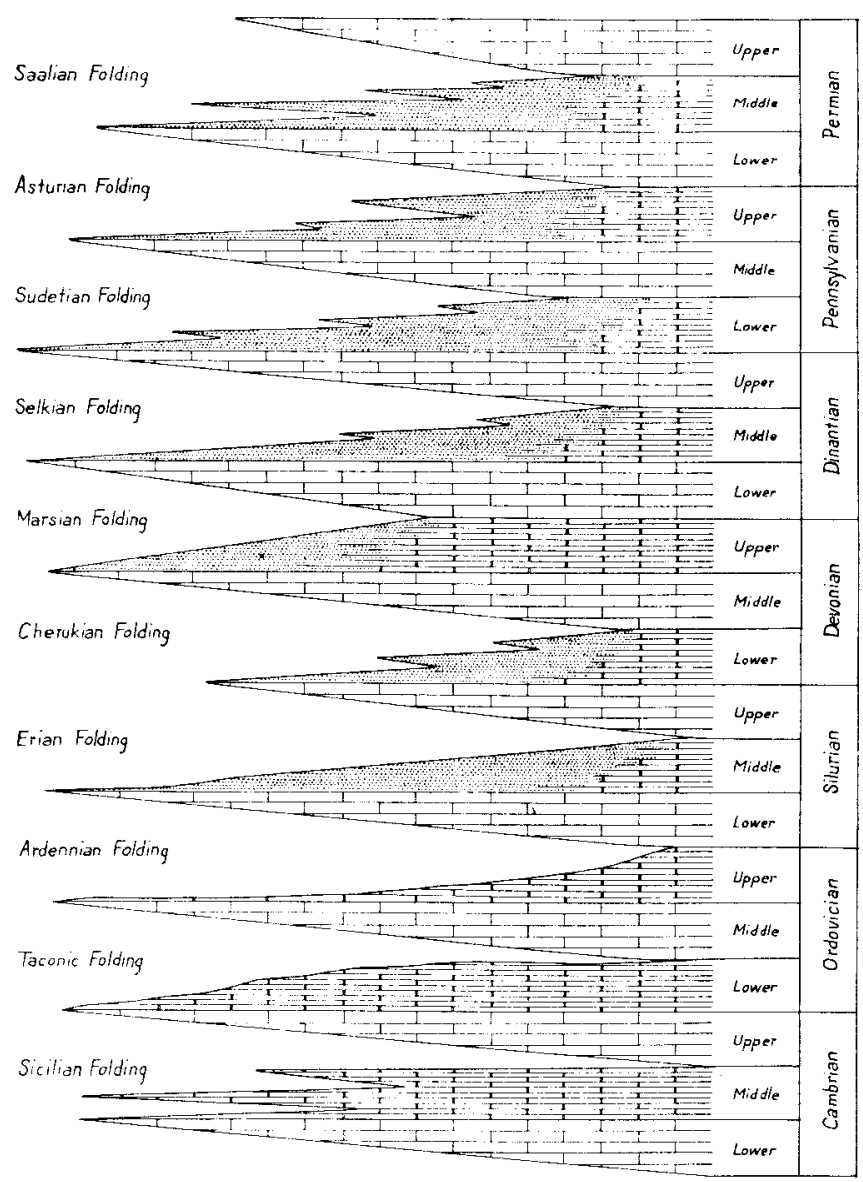

Figure 2: Grabau's "diagrammatic illustration of the overlaps due to transgression and the off-laps due to regression of the sea." Retreat phases are stippled, Grabau, 1933.

At the 1937 Moscow IGC, H. Lless (U.S.A.) combined his studies of orogenic ultramafic rocks with the gravityderived, downbuckle model of Vening Mleinesz, suggesting that crustal downbuckles would be found beneath mountain systems as well as in island ares. He also concluded (Hess, 1939, and see Fig. 3 of Maxwell, this issue) that the ultrabasics present in most orogenic belts were squeezed up along the axes of the downbuckles. Ophiolites are now viewed as remnants of oceanic erust and upper mantle obducted or carried upward during subduction or in the process of continental collision. In North America it was concluded from examination of geosynclinal rocks that eugeosynclines were founded on sialic crust, although the association of radiolarian cherts with ophiolites suggested a deep-water association, with resulting simatic crust, to many European geologists.

In London at the 18th IGC (1948), Ph. Kuenen, from The Netherlands, reported on flume experiments that suggested high-density mixtures of water and sediments could behave as underwater avalanches and move down slope at very high velocities leaving behind beds of graded sediments. This model was confirmed in nature on the deep sea floor. It led to the recognition that many eugeosynclinal sediments had the characteristics of turbidites and to new thinking, in North America at least, about the nature of the basement rocks beneath geosynclines and the structural position of eugeosynclines.

As early as 1875 , H.F. Blanford had recognized evidence for geological connections among the southern continents in Paleozoic time. Early models of these connections (Neumayr, 1895) took the form of land bridges that subsequently disappeared without a trace, but the concept of continental drift offered an alternative explanation. The need for workers from the Gondwanaland countries to have a forum for discussion was recognized during the 15 th IGC in Pretoria (1929), and the International Commission for the Correlation of the Karoo (Gondwana) System was established. The Commission held its first meeting at the 16 th IGC in Washington, D.C., hardly a hotbed of continental drifters at that time.

At the 16th Congress in Washington (1933) A.W. Grabau, an American then resident in China, plotted transgressions and regressions of the sea through much of Phanerozoic time and found that they matched very well with Stille's orogenic revolutions. These cycles were episodic with a period of about 30 million years (Fig. 2), in common with some recent suggestions about the periodicity of organic extinction in the geological record, but not in very good agreement with the oscillations determined by modern seismic stratigraphy.

At the (1937) Moscow Congress, Schatsky, from the Soviet Union, pointed out that Stille's short orogenic phases separated by long periods of quiescence are the same as the catastrophic epochs of Elie de Beaumont and referred to them as "neocatastrophism." His work suggested that folding is a long and slowly developing process and that orogenic and epeirogenic processes go on simultaneously. Although he was not a mobilist in principle, his thinking was more in accord with modern plate tectonics than that of those who believed in short orogenic phases.

\section{New Perspectives from the Oceans}

It is not surprising that much of the data that converted the fixists to mobilists came from the oceans. Although Wegener had drawn some very prescient conclusions, little was actually known about the structure and tectonics of the sea floor prior to 1950, and earlier ideas about global tectonies were based on features to be found on the continents. The first session on submarine geology, at a Congress, was held during the 2lst Congress in Copenhagen (1960). However, similar sessions did not recur until the 24 th IGC in Montreal (1972), when plate tectonics made its first appearance as a part of the Congress program.

As new geological, geophysical and geochemical tools became available and information began pouring in, it became apparent that there were serious problems with the concept of ancient ocean basins, with land bridges as a means by which organisms could migrate from one continent to another, and with global contraction, or expansion, as mechanisms for producing the Earth's surface features. In the mid-1960s a combination of geophysical and geological data, together with some inspired insight by an international 
collection of earth scientists, led to the conclusions that the ocean basins were geologically young and that the continents had indeed moved. Coupled with this was new geophysical evidence that strongly favored the concept generated from geodetic data (Barrell, 1914-15) and supported by seismology (Gutenberg, 1926) that the Earth's outer shell, the lithosphere, rested on a more plastic substratum, the asthenosphere.

The continents rode on this lithosphere; they did not need to plow through the oceans. With the subsequent demonstration of underthrusting (subduction) associated with the zones of deep earthquakes first mapped by the Japanese seismologist Wadati (1935), and the realization that most of the tectonic activity was taking place along the boundaries of large lithospheric plates associated with these, and with the axis of the ocean ridge system, plate tectonies was born.

\section{The Decade of North American Geology}

At the fifth IGC, held in Washington in 1891, the geology of the U.S.A. was viewed in terms of fixed continents with the structures resulting from primarily vertical forces. By the time of the 1933 Congress, the next to be held in the U.S.A., continental drift had been suggested, but the general concensus of opinion remained behind fixed continents. As the 28th IGC approaches, opinions have changed and plate tectonics is the accepted model, even though most of the detailed syntheses of the geology of the U.S.A. had been produced before this concept existed.

About a decade ago, the Geological Society of America decided to undertake a major project, the Decade of North American Geology (DNAG), to commemorate its centennial in 1988. This venture involves geologists from Canada, Mexico, Central American countries, the U.S.A., and cooperating groups in Greenland and Iceland to produce a new synthesis of the geology of North America. Its principal objective is to produce, in collaboration with other societies and with geological surveys of participating countries, a multi-volume set of books, together with geological and geophysical maps, that will represent a modern synthesis of the geology of North America in terms of the new tectonic model. Contributors to this issue of Episodes, summarizing the geology of the United States, have played significant roles in the preparation of these volumes and maps. The series is scheduled to be completed in 1988 and should be available to interested geologists at the time of the $28 \mathrm{th}$ IGC. It will represent the foundation upon which future geological investigations in the United States are based.

Prof. C.L. Drake, (Dept. Earth Sciences, Dartmouth College Hanover, NH 03755, U.S.A.) is President of the 28th International Geological Congress. He is a member of the IGCP Board and was President of the ICSU Commission on Geodynamies from 1970-76, the Geological Society of America in 1976-77, and the American Geophysical Union from 1984-86. His research interests are in continental margins, geodynamics and major discontinuities in the geological record.

\section{References}

Argand, E., 1922. La Tectonic de l'Asie. Comptes Rendues 13th International Geological Congress, Belgium. H. Vaillant-Carmanne, Liege, p. 172-372.

Barrell, J., 1914-15. The Strength of the Earth's Crust. Journal of Geology, v. 22 , p. $28-48,145-165,209-236$, 289-314, 441-468, 537-555, 655-683, 729-741; v. 23, p. 27-44.

Blanford, H.F., 1875. On the Age and Correlations of the Plant-Bearing Series of India, and the Former Existence of an Indo-Oceanic Continent. Geological Society of London Quarterly Journal, v. 31 , p. 519-542.

Grabau, A., 1933. Pulsations or Oscillations. I6th International Geological Congress, Washington, D.C.

Gutenberg, B., 1926. Untersuchungen zur Frage, bis zu welcher Tiefe die Erde Kristallin ist. Zeitschrift für Geophysik, v. 2, p. 24-29.

Hess, H.H., 1938. Island Ares, Gravity Anomalies and Sepentine Intrusions. A Contribution to the Ophiolite Problem. 17th International Geological Congress, Moscow, 1937, v. 2, p. 263-283.

Kuenen, Ph., 1948. Turbidity Currents of High Density. Proceedings of the $18 \mathrm{th}$ International Geological Congress, Part VIII, London, p. 44-52.

Neumayr, M., 1895. Erdgeschichte Vol. 2, Beschriebende Geologie, 2nd ed. Leipzig und Wien, Bibliographisches Inst.

Schatsky, N.S., 1939. Orogenic Phases and Folding. 17th International Geological Congress, Moscow, 1937, v. 2, p. 305-311.

Steinmann, G., 1926. Die Ophiolitischen Zonen in den Mediterranean Kettengebrigen. Comptes Rendues 14th International Geological Congress, Madrid, p. 638-667.

Wadati, K., 1935. On the Activity of Deep Focus Earthquakes in the Japanese Islands and Neighborhoods. Geophysical Magazine, v. 8, p. 305 .

Wegener, A.L., 1912. Die Enstehung der Kontinente. Geologische Rundschau, v. 3, p. 276-292; Die Enstehung der Kontinente, Petermanns Geographische Mitteilungen, v. 58, p. 185-195, 253-256, 305-309.

\section{NEED TO MATCH SCALES ACCURATELY?}

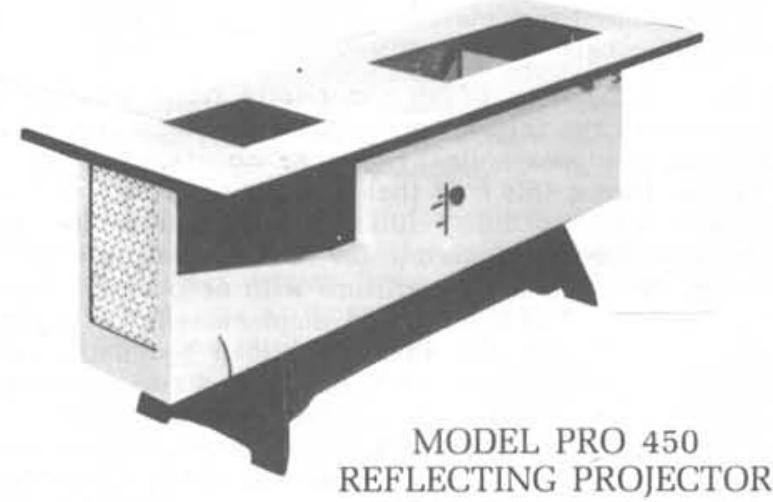

- Finest quality Optics

- Motorized controls

- 1st Surface mirrors

- 4.5X Enlargement to .22X Reduction

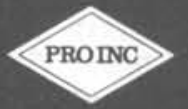

- Precise \& dependable operation

- Table-top convenience

- Decorator colors

- Bright clear image

For a well crafted projector, at a reasonable price. with fast delivery, please write or phone: 